\title{
New record and site characterization of a hibernating colony of Myotis velifer in a mountain ecosystem of central Mexico
}

\author{
Jorge Ayala-Berdon ${ }^{1 *}$ and Víctor Solís-Cárdenas ${ }^{2}$ \\ ${ }^{1}$ CONACYT, Universidad Autónoma de Tlaxcala, Carretera Tlaxcala-Puebla Km. 1.5, CP. 90062, Tlaxcala de Xicohténcalt, Tlaxcala, \\ México. Email:jorgeayalaberdon@gmail.com (JAB). \\ ${ }^{2}$ Facultad de Estudios Superiores Iztacala, Universidad Nacional Autónoma de México, Av. De los Barrios 1, Los Reyes Iztacala, \\ Estado de México, CP. 54090, Tlalnepantla de Baz. Estadod e México, México. Email: pteridobiontemesofilo@gmail.com (VSC). \\ ${ }^{*}$ Corresponding author
}

Hibernation is a strategy allowing bats to save energy when food availability and ambient temperature are low. Four decades ago, an altitudinal migration of the bat Myotis velifer to a hibernating site was registered in Mexico. However, no records or characterization of the sites used by this species to hibernate in the country are virtually known. Our main objective was to describe and characterize a hibernating colony of Myotis velifer in a tunnel located at 3,600 meters above sea level in La Malinche National Park, a mountain ecosystem of central Mexico. From June 2015 to May 2016, we visited the tunnel each month. In each visit, we looked for bats and made a one-time measurement of ambient temperature and relative humidity. During the first visit to the tunnel, we randomly captured and measured (i. e., sex, length of the forearm, body mass, and reproductive condition) seven individuals for information purposes. These individuals were released at the end of procedures. In mid September 2015, we found 14 M. velifer hibernating in clusters of different sizes. By mid January, the colony reached 81 individuals. We not longer found bats when we visited the tunnel in middle March. Ambient mean temperature and humidity were $7.5 \pm 1.5{ }^{\circ} \mathrm{C}$ and $70 \pm 8.3$ $\%$ respectively. Our new record of the hibernating colony of $M$. velifer exemplifies the specificity of hibernacula used by this species in central Mexico. The six-month period of hibernation and environmental variables we recorded match with the interval that $M$. velifer has been reported hibernating at other latitudes. Currently, characterizing the environmental requirements of bats to hibernate is of relevance to promote specific conservation strategies for this group of vertebrates.

La hibernación es una estrategia que le permite a los murciélagos ahorrar energía cuando la disponibilidad de alimento y la temperatura ambiental son bajas. En México, hace cuatro décadas se llevó a cabo un registró del murciélago Myotis velifer migrando altitudinalmente a un sitio de hibernación. Sin embargo, no se conocen en el país los registros y las características de los sitios utilizados por esta especie para hibernar. Nuestro objetivo principal fue describir y caracterizar una colonia de hibernación de Myotis velifer en un túnel situado a 3,600 metros sobre el nivel del mar en el Parque Nacional La Malinche, un ecosistema de montaña del centro de México. De junio de 2015 a mayo de 2016 , se llevaron a cabo visitas al túnel cada mes. En cada visita, se buscaron murciélagos y se tomaron medidas únicas de temperatura ambiental y humedad relativa. Durante la primera visita al túnel, capturamos y medimos aleatoriamente (i.e., sexo, longitud del antebrazo, masa corporal y estado reproductivo), siete individuos con fines informativos. Estos individuos fueron liberados al término de los procedimientos. A mediados de septiembre de 2015, encontramos 14 M. velifer hibernando en grupos de diferentes tamaños. A mediados de enero, la colonia alcanzó 81 individuos. No se encontraron murciélagos cuando visitamos el túnel a mediados de marzo. La temperatura ambiental y la humedad relativa media fueron de $7.5 \pm 1.5^{\circ} \mathrm{C}$ y $70 \pm 8.3 \%$ respectivamente. Nuestro nuevo registro de la colonia de $M$. velifer hibernando ejemplifica la especificidad de los refugios utilizados por esta especie en el centro de México. El período de seis meses de hibernación y las variables ambientales registradas coinciden con el intervalo en el que $M$. velifer ha sido reportado hibernando en otras latitudes. Actualmente, la caracterización de los requisitos ambientales de los murciélagos para hibernar es de relevancia para promover estrategias de conservación específicas para este grupo de vertebrados.

Keywords: central Mexico; hibernation; insectivorous bats; mountain ecosystem.

C 2017 Asociación Mexicana de Mastozoología, www.mastozoologiamexicana.org

\section{Introduction}

The cave Myotis (Myotis velifer) is a medium-sized insectivorous bat ( 35 to $46 \mathrm{~mm}, \sim 15 \mathrm{~g}$ ), which is distributed throughout the United States in Kansas to southern Nevada, and southeastern California, extending to Mexico and Honduras (Fitch et al. 1981). This species is typically a cave dweller that is often found in mines, tunnels, and occasionally in buildings or under bridges (Hayward 1970; Davis and Cockrum 1963). Its diet is mainly composed of beetles (Coleoptera) and moths (Lepidoptera; Kunz 1974). Myotis velifer regulates population growth of many insect herbivores, and therefore, is of great importance for conservation of mountain ecosystems (Böhm et al. 2011).
Colonies of $M$. velifer reach sizes from 1,000 to 5,000 individuals in Arizona, Oklahoma, Kansas, and Texas, where populations appear to reside permanently (Tinkle and Patterson 1965; Fitch et al. 1981; Caire and Loucks 2010). In these sites, bats hibernate during winter (Hayward 1970; Samanie and Caire 2007). Hibernation may last up to six to eight months, allowing bats to save energy when food availability and ambient temperature are low (Lyman 1982). In Mexico, M. velifer form colonies in caves of 100 to more than 10,000 individuals along the country (Arita 1993). 50 years ago, Villa (1967) reported individuals of $M$. velifer migrating to high altitudes to the mountains in order to hibernate. However, there is no detailed information about 
the places used by this species to hibernate in the country, neither of the environmental conditions faced by bats in the hibernaculum. Our main goal was to describe and characterize a hibernation colony of $M$. velifer in a tunnel located in La Malinche National Park (LMNP), a mountain ecosystem in central Mexico.

La Malinche National Park is located in the Trans Mexican Volcanic Belt ( $19^{\circ} 06^{\prime} 04^{\prime \prime}$ and $19^{\circ} 20^{\prime} 06^{\prime \prime} \mathrm{N} ;-97^{\circ} 55^{\prime}$ $41^{\prime \prime}$ and $\left.-98^{\circ} 10^{\prime} 52^{\prime \prime} \mathrm{W}\right)$. The park is home for 11 bat species, seven of them belonging to the family Vespertilionidae (Ayala-Berdon et al. 2017). Here, we report for the first time a colony of $M$. velifer using a tunnel while hibernating in central Mexico. The hibernaculum is located in the East slope of the main runoff of the park $\left(19^{\circ} 14^{\prime} 19^{\prime \prime} \mathrm{N},-98^{\circ} 1^{\prime}\right.$ $10^{\prime \prime} \mathrm{W}$ ) at $3,600 \mathrm{~m}$. Surrounding vegetation is composed of dense patches of Abies forest and high mountain grasses (Villers et al. 2006). We visited the tunnel in the middle of each month, every 30 days, from July 2015 to March 2016. The tunnel is $23 \mathrm{~m}$ long, $1.8 \mathrm{~m}$ high and $1.6 \mathrm{~m}$ wide. In each visit, we looked for bats in the interior of the tunnel and made a one-time measurement of the ambient temperature and relative humidity. We visited the tunnel around midday each time. All measurements were done in the same place in the middle of the colony, $12 \mathrm{~m}$ away from the entrance. During the first visit to the tunnel, we randomly captured and measured (i. e., sex, length of the forearm, body mass, and reproductive condition) seven individuals (Table 1). Species identification was conducted following Medellín et al. (2008). Body mass was estimated by weighing the bats with an electronic balance to the nearest $0.1 \mathrm{~g}$ (Ohaus ${ }^{\circledR}$, Parsippany-Troy Hills, New Jersey). After all measurements were completed, to avoid bats flee from the cave and be predated, we transferred individuals to laboratory conditions ( $19{ }^{\circ} \mathrm{C}, 70 \%$ humidity) to La Malinche Biological Station, $5 \mathrm{~km}$ away from the tunnel. We retained bats until sunset, and released them near the tunnel that same night. Bats were captured under permission of the Department of Wildlife management (SEMARNAT, permit number 07019 granted to our institution).

In the tunnel, mean ambient temperature was $7.5 \pm 1.5$ ${ }^{\circ} \mathrm{C}$, while mean ambient relative humidity was $70 \pm 8.3 \%$, along the eight months sampled. These conditions are similar of those reported as preferred by $M$. velifer hibernating in other hibernacula. In Texas, Indiana and Kansas, M. velifer

Table 1. Individual bats of Myotis velifer captured on September 2015 in a tunnel located at 3,600 m in La Malinche National Park, a mountain ecosystem of central Mexico. None of the bats were reproductive.

\begin{tabular}{cccc}
\hline Individual & Sex & Forearm $(\mathrm{mm})$ & Body mass $(\mathrm{g})$ \\
\hline 1 & $\mathrm{M}$ & 46.2 & 10.6 \\
2 & $\mathrm{~F}$ & 46.0 & 11.4 \\
3 & $\mathrm{~F}$ & 43.5 & 11.0 \\
4 & $\mathrm{~F}$ & 45.1 & 12.2 \\
5 & $\mathrm{M}$ & 44.1 & 10.4 \\
6 & $\mathrm{~F}$ & 44.4 & 11.0 \\
7 & $\mathrm{M}$ & 42.3 & 10.6 \\
\hline
\end{tabular}

$M=$ male, $F=$ female hibernates in caves with temperatures ranging from 1 to 10 ${ }^{\circ} \mathrm{C}$ and a relative humidity from 70 to $100 \%$ (Tinkle and Patterson 1965; Webb et al. 1996). In mid September 2015, we found 14 individuals of $M$. velifer hibernating in clusters of different sizes. All clusters were composed by $M$. velifer, and we only observed one individual of Corynorhinus mexicana resting alone and sharing the tunnel with our study species. Clustering has been previously reported for the species as a way to reduce the energetic expenditures caused by low ambient temperatures (Tinkle and Patterson 1965). By mid January, the colony reached 81 individuals. We are confident that bats were hibernating, because they were unresponsive to our presence and most individuals remained until mid-February. Bats were not disturbed in subsequent visits to the tunnel. M. velifer has been reported hibernating at other latitudes during the same six-month period and in the same environmental conditions (Fitch et al. 1981).

Hibernation is an important physiological process that determines the survival of bats during winter, when food is scarce and the ambient temperature is low (Lyman 1982; Speakman and Thomas 2003). This new record exemplifies the specificity of hibernaculum used by bats in central Mexico. In the last decade, LMNP has suffered a huge anthropogenic pressure (i. e., illegal logging, grazing and firing; Chávez et al. 1990; Espejel 1996). To date, its vegetation has been reduced by $77 \%$ since the reserve was decreed (Díaz Ojeda 1992; Vargas-Márquez 1997). Currently, characterizing the environmental requirements of bats to hibernate is of relevance to promote specific conservation strategies in the country for this group of vertebrates.

\section{Acknowledgments}

The authors thank La Malinche Biological station for its logistical support. K. Medina and A. Soto helped in data collection and the visits to the tunnel. M. Vázquez, N. Rodríguez, A. Díaz de la Vega and S. Ancona made valuable comments of the content of the manuscript. The program Por Amor al Planeta 2013 by the Volkswagen Company financed the fieldwork.

\section{References}

ARITA, H. T. 1993. Conservation biology of the cave bats of Mexico. Journal of Mammalogy 74:693-702.

Ayala-Berdon, J., R. Vázquez-Fuerte, N. Rodríguez-Peña, and M. Martínez-Gómez. 2017. Bat fauna associated with artificial ponds in La Malinche National Park, a mountain ecosystem of Mexico. Mammalia (ahead of print) DOl:https://doi. org/10.1515/mammalia-2016-0055.

BöHM, S. M., K. WelLS, AND E. K. KalKo. 2011. Top-down control of herbivory by birds and bats in the canopy of temperate broad-leaved oaks (Quercus robur). PLoS One 6:e17857. doi:10.1371/journal.pone.0017857.

CAIRE, W., AND L. S. Loucks. 2010. Loss in mass by hibernating Cave Myotis, Myotis velifer (Chiroptera: Vespertilionidae) in western Oklahoma. The Southwestern Naturalist 55:323-330. Chávez, C. J., M. Ramos, and N. Trigo. 1990. Plan de manejo 
integral para el Parque Nacional "La Malinche" y su área de amortiguamiento. Cuadernos del CIIH. Serie Fuentes-UNAM, 1:217-237.

DAVIS, R., AND E. L. CoCKRUM. 1963. Bridges utilized as day-roosts by bats. Journal of Mammalogy 44:428-430.

DíAZ, O. E. V. 1992. Informe del Parque Nacional Malinche. Jefatura del Programa Forestal de Tlaxcala, Tlaxcala, México.

ESPEJEL, A. 1996. La Malinche: una visión retrospectiva de su deterioro y conservación. Gaceta Ecologica 41:14-21.

Fitch, J. H., K. A. Shump, And A. U. Shump. 1981. Myotis velifer. Mammalian Species 149:1-5.

HAYWARD, B. J. 1970. The natural history of the cave bat, Myotis velifer. Western New Mexico University Research and Science $1: 1-74$.

Kunz, T. H. 1974. Feeding ecology of a temperate insectivorous bat (Myotis velifer). Ecology 55:693-711.

Lyman, C. P., J. S. Willis, A. Malan, And L. Wang. 1982. Hibernation and torpor in mammals and birds. AP Academic Press. New York, U. S. A.

Medellín, R. A., T. H. Arita, And Ó. Sánchez. 2008. Identificación de los murciélagos de México: clave de campo. Instituto de Ecología, UNAM. Ciudad de México, México.

Samanie, L. M., And W. Caire. 2007. Sex ratio variation of Myotis velifer (Chiroptera: Vespertilionidae) in Oklahoma. The Southwestern Naturalist 52:67-74.

Speakman, J. R., and D. W. Thomas. 2003. Physiological ecology and energetics of bats. Pp. 430-490 in Bat ecology (Kunz, T. $\mathrm{H}$., and M. B. Fenton, eds.). The University of Chicago Press. Chicago, U.S. A.

TinkLe, D. W., AND I. G. PAtTerson. 1965. A study of hibernating populations of Myotis velifer in northwestern Texas. Journal of Mammalogy 46:612-633.

Vargas-Márquez, F. 1997. Parques Nacionales de México. Aspectos físicos, sociales, legales, administrativos, recreativos, biológicos, culturales, situación actual y propuestas en torno a los Parques Nacionales de México. SEMARNAP. Instituto Nacional de Ecología. Ciudad de México, México.

VitLA, R. B. 1967. Los murciélagos de México. Instituto de Biología. Universidad Nacional Autónoma de México. Ciudad de México, México.

Villers, R. L., F. Rojas, and P. Tenorio. 2006. Guía Botánica del Parque Nacional Malinche, Tlaxcala-Puebla. Centro de Ciencias de la Atmósfera e Instituto de Biología. Ciudad de México, México.

Webb, P. I., J. R. Speakman, and P. A. Racey. 1996. How hot is a hibernaculum? A review of the temperatures at which bats hibernate. Canadian Journal of Zoology 74:761-765. 
HIBERNATING MYOTIS VELIFER

174 THERYA Vol. 8(2): 171-174 